\title{
Design Guidance for Fracture-Critical Components at Lawrence Livermore National Laboratory
}

\author{
R. D. Streit
}

Manuscript date: March 3, 1982

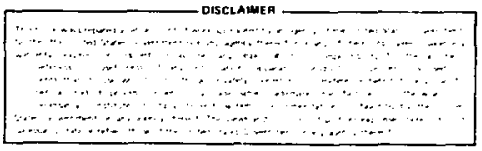

LAWRENCE LIVERMORE LABORATORY University of California $\bullet$ Livermore, California 994550 


\section{PREFACE}

The purpose of this document is to define the areas in which various fracture-safe design aprroaches must be applied. Various decisions had to be made concerning the consequences involved if fracture of a component should occur. In general, there are no clear cut lines of distinction between consequences. Thus, it is important for designers and engineers to assess the consequences of failure of a structure being analyzed in a way compatible with this document. It is useful to put oneself in the position of the user and ask, "How safe do I feel?" Then, based on the answer to this question, decide what level of safety in design is appropriate.

The cost of a failure and relative safety levels chosen are based on what I have observed over the last few years at this Laboratory. As conditions change (either technological, economic, etc.) this document should be changed to reflect the current philosophy. As such, it is important that the users provide constructive input on the use of this guidance to the author, so that it can be properly updated as necessary.

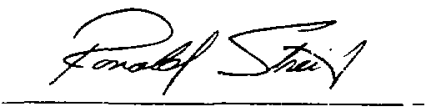

R. D. Streit 


\section{CONTENTS}

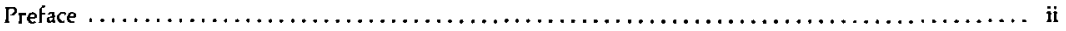

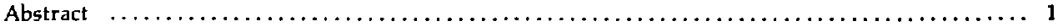

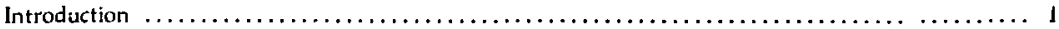

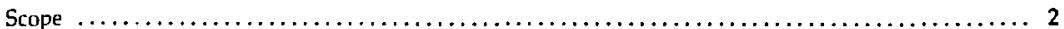

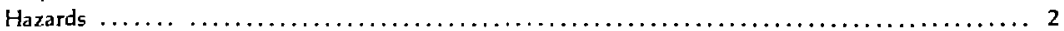

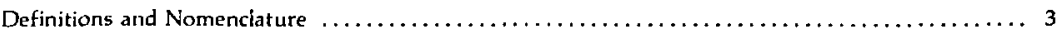

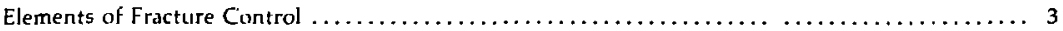

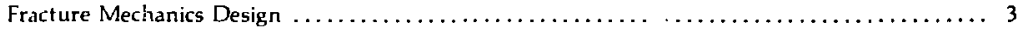

Basis of Fracture Control Plan $\ldots \ldots \ldots \ldots \ldots \ldots \ldots \ldots \ldots \ldots \ldots \ldots \ldots \ldots \ldots \ldots \ldots \ldots, 7$

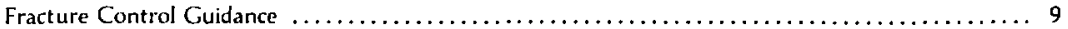

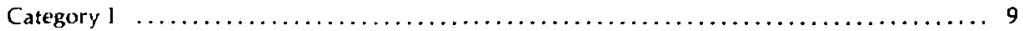

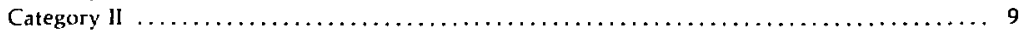

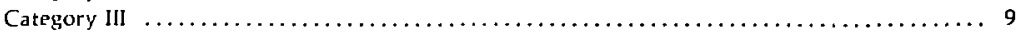

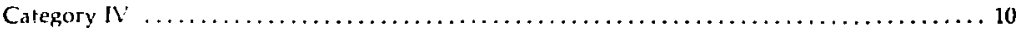

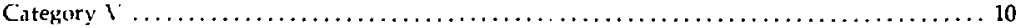

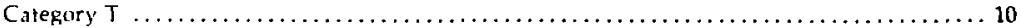

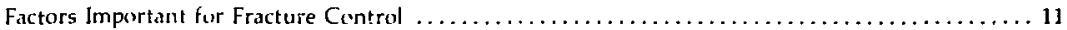

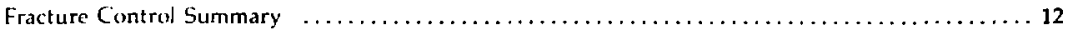

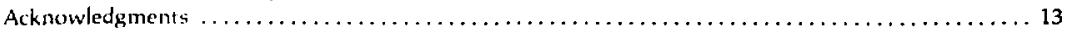

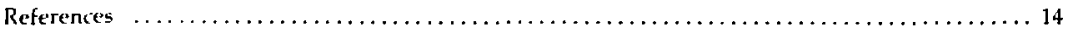




\title{
Design Guidance for Fracture-Critical Components at Lawrence Livermore National Laboratory
}

\begin{abstract}
Fracture is an important design consideration for components whose sudden and catastrophic failure could result in a serious accident. Elements of fracture control and fracture mechanics design methods are reviewed. Design requirements, which are based on the consequences of fracture of a given component, are subsequently developed. Five categories of consequences are defined. Category $I$ is the lowest risk, and relatively lenient design requirements are employed. Category $\mathrm{V}$ has the highest potential for injury, release of hazardous material, and damage. Correspondingly, the design requirerilents for these components are the most stringent. Environmental, loading, and material factors that can affect fracture safety are also discussed.
\end{abstract}

\section{INTRODUCTION}

Because of the sudden and often catastrophic nature of britlle fracture, it is important to consider fracture mechanics in the design of all eomponents whose failure could result in personiel injury, relectse of hasardous or radionctive material, or loss ot time and mumey. The primary a ause of such failures is the growth of small flaws duc (1) hading and environment until such size that the structure becomes unstable and failure excurs Accurdingly, there are three basic elements to fracture control: (1) loading, (2) crack ste and peonetry, and (3) resistance to crack propagation in the appropriate environment.

Understanding all factors that affect frature in a complex structure is not possible. Thus, a fracture control plan is employed to systematically consider the primary fracture ele:nents in the design, fabrication and use of fracture critical components. ${ }^{[-3}$ The responsible engineer must correctly identify the inpui to the fracture control evaluation and assess all conditions (e.g., dynamic loading, corrosive environments, brittle welds, etc.) that may prove critical to the design integrity. The section on Factors Important for Fracture Control will aid in this evaluation. The Laboratory's Engureering Sciences Division can also provide important technical advice in such circumstances.
For the purpose of this document, fracture critical components are divided into five main categories: based upon their potential conseyuences should fracture occur. Categary 1 is the lowest risk thus requiring minimal fracture guidance; whereas Category ' $\mathrm{l}$ ' has the highest potential for personnel injury and damage. Correspondingly, ritegory l' components are designed and tested to the highest standards.

The five categuries are as follows:

Category I: Fuilute has essentially no potential to cause injury and the cost of failure is low (1.e. less than \$5000).

Examples: Small equipment, low pressure pi,ping.

Category II: Failure has essentially no potential to cause injury, but the cost of failure is moderate li.e. cost to repair is between $\$ 5000$ and $\$ 50.000$ ).

Example: Remote operation equipment such as a high volume hyciraulic pump.

\footnotetext{
- Temporary and test equipment are covered by a sixth alepory. Category T.
} 
Category III: Failure has pctential for only minor injury (i.e. only first aid necessary) and cost to repair failure is low to moderate (i.e., cost to repair is less than $\$ 50,000$ ).

Example: Lifting devices (i.e., hooks, fork lift) where personnel are cleared from immediate area.

Category IV: Failure has the potential for moderate injury (i.e., does no: requirs hospitalization) and/or the cost of repairs are high (greater than $\$ 50,000$ ).

Exanvale: Remute operation of a high pressure vessel.

Category: $\checkmark$. Failure can result in severe injury andior the release of hazardous or radio. active inaterial. In this bategory the cost of failure is usually high: however, the potential for miry or hazardous release is the overriding concern
Example: Tritium vessel or manned area high pressure vessel.

Only cases in which there is a potential for injury or release of hazardous materials is a fracture control plan required. Other cases are presented as fracture guidance. The engineer is cautioned, however, that the cost of failure due to downtime, replacement cost, and other incon-veniences can be high even in noninjury cases.

An ME safety note may be required for designs of some fracture-critical components. Thic safety note must include a fracture control plan that states how the fracture-bafe design criteria are met by the design, material, fabrication, and service conditions. To assess what insigns will require a safety note, see the LLNL Health and Safety Manual ' and the ME Department's Design Sifety Standards.

\section{SCOPE}

Wany factors influence the design and material regurements of iracture-critical components. Il wauld be imporsible to detail a specific fracture cont rol plan to cuver the range of laboratory needs. The goisl of thas document is to provide the designer and engmeer with the necessary in. formation and design guidance to assess the role that fracture control will play in the design and fabrication of a given structure. It is the enigneer's responsbility to develop or otherwise obtain a fracture control plan that is appropriate for the structure and safety level requirements. This re- port establishes guidance for such a fracture control plan.

A miaber of fracture conerol plans are avialable trom technical stretetes. undustry, and government. 10 "Where the scone of these plans as compatible with the component under evalualan, their use is atceptable In any case, however. it is important to consult with the Engineering Sciences Division to and in the develenment of a fracture cuntral plan or to ensure that the critical elements of fracture control are adequately addressed in existing plans.

\section{HAZARDS}

A structure that is nat fracture-safe can fail by sudden, catastrophic propagation of a crack at nominal stresses as low as a small fraction of the yield strength of the material. Factors affecting fracture safety include material properties, temperature, environment, component geometry, as well as the flaw size and its gecumetry. The temperature at which some materials have inadequate resistance to crack propagation can be ahove normal ambient temperatures. Depending upon the tvpe of structure, energy potential, and proximity to personnel, the hazard can vary considerably. In addition to loss of function of the fracture-critical structure, explosion, flying debris, and loud noise may accompany failure. 


\section{DEFINITIONS AND NOMENCLATURE}

\begin{tabular}{|c|c|}
\hline$a, c$ & flaw dimensions \\
\hline B & specimen or component thickness \\
\hline $\mathrm{B}_{y}$ & $\begin{array}{l}\text { specimen or component thickness limita- } \\
\text { tion for plastic yielding }\end{array}$ \\
\hline 8 & Charpy V-notch \\
\hline $\mathrm{T}$ & dynamic tear \\
\hline$E^{\prime}$ & $\begin{array}{l}\text { elastic modulus adjusted for planc strain; } \\
E /(1-1,2) \text {, where } E \text { is the elastic modulus }\end{array}$ \\
\hline & $\begin{array}{l}\text { and } y \text { is Poisson's ratio } \\
\text { applied stress intensity }\end{array}$ \\
\hline
\end{tabular}

$K_{k} \cdot J_{k}$ plane strain fracture toughness. The two parameters are related by the relation

$$
J_{\mathrm{k}}=\left(\mathrm{K}_{\mathrm{l}}^{2} / \mathrm{E}^{\prime}\right)
$$

$K_{\text {la }} \quad$ crack arrest toughness

$K_{\text {id }}$ plane strain fracture toughness for dynamic loading

$S_{u} \quad$ ultimate tensile strength

Sy yield strength

\section{ELEMENTS OF FRACTURE CONTROL}

Linear elastic frature mechanics (LEFM) is a design tool in which the brittle tracture of structures can be predicted through component loading and either resl or postulated cracks. By ensuring that the $;$ ing stress intensity levith an approprate factor of safetyl is less than the material fracture toughness fevaluated for the specific environment and loading 1, unstable crack propagation can be avesided. This design relalienship is anakgous to the association of a component's stress state and the material tensile properties. LEFM enablen the erigineer to evaluate a maleral's resistance to crack propagation and thus preside a basis by which given materials nay be certified for fracture critical applications. In additun to materal certification, lests based (1) fracture come ept ti.e., Charpy and dynamic tearı. are often used for streening materials and in the surveillante of material degradation.

Varisus design philosophies may be employed in tracture-sate design. A few commen practices Include: designing for an allowable "lifetime" based (n) tatigue crack-growth predictions; employing fail-safe concepts based on large plastic deformatoon, multiple laad paths or redundant members: providing for leak-before break; and/or developing suitable inspection procedures. Although differing in applicatum, all methods are armed at ensuring that the crack sires remain less than the critical sise for brittle fracture. Fracture control plans are a usctul means of emnloying the required design philosophies.

\section{FRACTURE MECHANICS DESIGN}

Mechanical engineering design generally encompasses structural syrthesis, analysis, material selection, and design stress-level evaluation. The engineer uses fracture mechanics as one of his tools by which to choose materials, design stress levels, and alliwabie crack sizes for inspection or quality control to athieve the goal of a safe design.

The stress-intensity factor is related to the nominal stress, geometry and flaw sire by

$K_{1}=$ Flgeometry) $1 \bar{a}$.

where F is a constant that depends only on the geometry of the part and crack, $a$ is the inminal stress, and $d$ is the crack sice. Frature will occur when the stress level and/or track length is increased such that

$K_{1} \leq K_{1}$

where $K_{\text {. }}$ is the critical stress-inlensity factor for a particular materisl (including heat-treatment. weldnents, etc.) at a given temperature, loadsng rate, and environment. Under plane strain sonditions, the critical stress intensity is replaced by the material's fracture toughness $K_{\mathrm{l}}$. dynamic fracture toughness $K_{i d}$, or crack arrest toughness $K_{1,1}$, based on the desigr conditions. Many references are available for fracture toughness data. A 
useful compendium of sources is given in Ref. 10. Thus, the three factors that influence fracture control are: (1) allowable design stress level, which is often a function of the "rated-capacity" of the component; (2) flaw size and shape, which can be monitored by quality assurance and inspection techniques; and (3) toughness of the material, which is controlled by selection and processing.

Stress intensity solutions for many useful geometries an be easily found in available handbooks 11.12 and technical publications. The stress intensity solution for a through-thicknesscrack of length 2 in a large plate (Fig. 1 ) is

$K_{1}=\pi \sqrt{\pi a}$

This formulation of the stress intensity is extremely useful for intial estimates of critical crack size, recpuired toughness level, or safe working stress. Correction factors can be found in the literature to account for plate dimensions, nonsvmmetric loading, or a nonsymmetricilly located irack. Similarly, solutions for edge cracks in plates atten provide a useful starting point for the fracture analysio of some geonetries (Fig. 2).

Vany of the cracks found in prictice arise from such things as weld defects, an burns.

FIG. 1. Through-wall crack geometry in a large plate and associaled stress intensity solution. corrosion pits, machining marks, or other defects in manufacture. These cracks are generally approximated by the thumbnail track shown in Fig. 3. Even in thin plates, the leading edge of such a thumbnail crack could be subjected to plane strain constraint, so the corresponding fracture tuughness may be low.

For relatively small elliptically shaped flaws $(a<B / 2)$ and a nominal stress well below yield, the critical flaw size is given by

$$
\begin{aligned}
& a=\frac{1}{1.21 \pi}\left(\frac{K_{h_{h}}}{0}\right)^{2} \text { for a surface flaws or } \\
& a=\frac{1}{\pi}\left(\frac{K_{h}}{0}\right)^{2} \quad \text { for a buried flaw. }
\end{aligned}
$$

In the nure seneral case the flaw depth $Q$ is replaced by $a / Q$. $Q$ is a flaw shape factor that accounts for the crack aspect ratio a/c, and stress level. It can be evaluated from Fig 3.

(Ince the critical stress for erack propagat two has been reached, the thumbnal crack will uf ten grow through the plate tobecome a through. thickness crack A value often quoted for this subseguent thruegh crack length is $2 B$. Whether

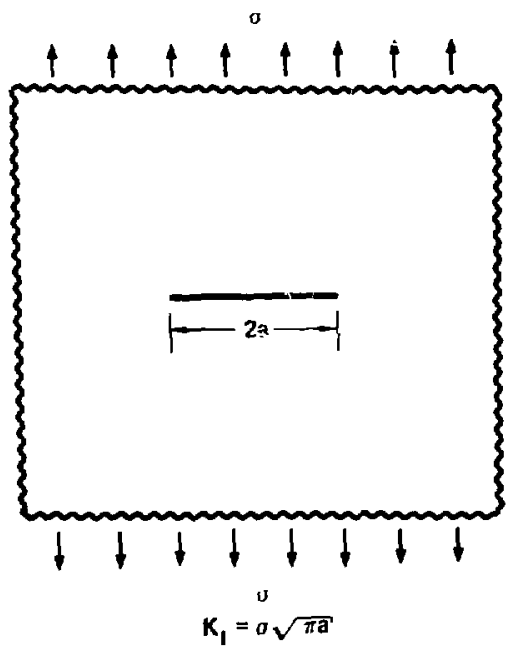


$\sigma$

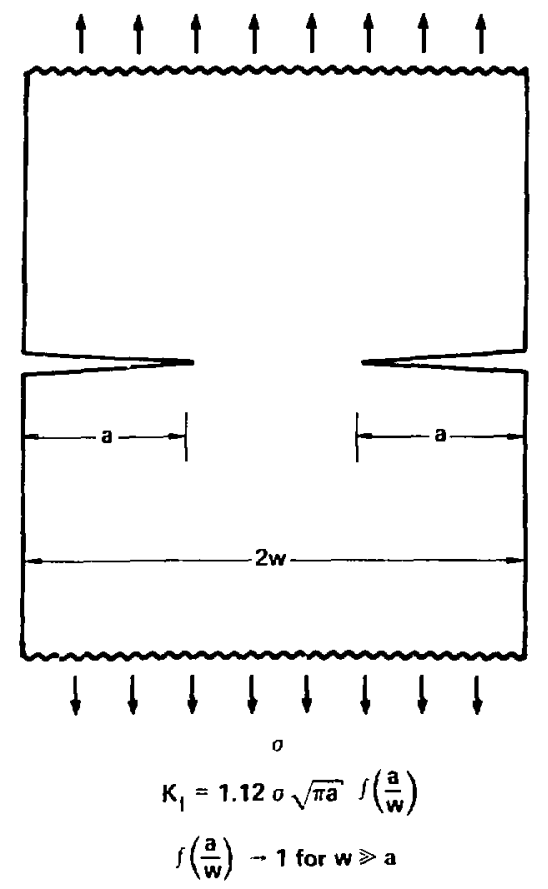

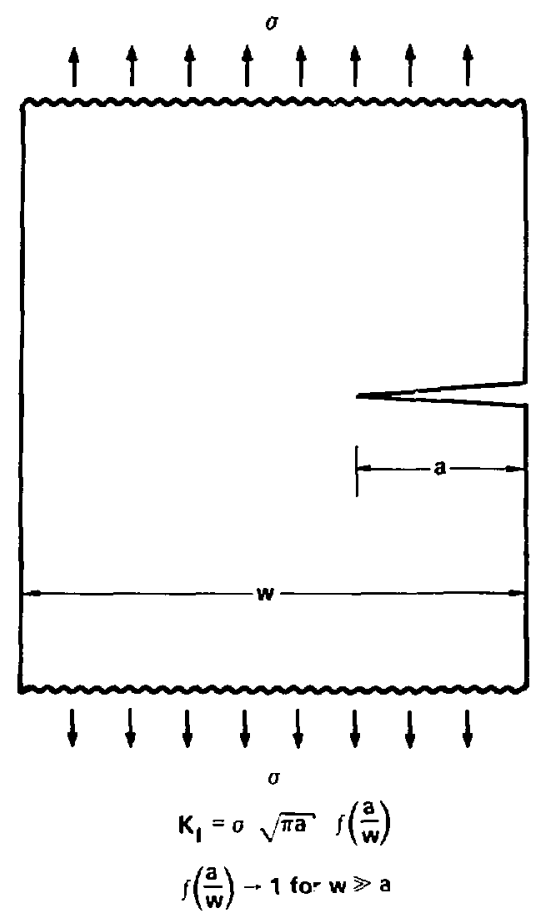

FIG. 2. Edge-notched geometries and associated stress intensity solutions.

the through cratk arrests will depend en its length and the balue of $\mathrm{K}_{\mathrm{a}}$ for the plate thickness. Thus in thin sheets, with large $K_{6}$, if a small crack is fermussble, it may be less restrictive to design agamst propagation of the through crak. However, it the structure has to contain presiure for long periedi, e.g, a gas storage pressure vessel, then propagation of thumbnail cracks may have to be considered. In thick plates, the value of $\mathrm{K}_{\mathrm{Ic}}$ may be low enough so that ance the thumbnail crack grows into a through crack there isn't much hance of stopping it. In this case, design has to be based on thumbnail flaws.

As an example of fracture-critical design, in 1905 a large rocket motor case failed while under hydrostatic test due to an internal flaw about 0.8 by $1 . t \mathrm{in}$. The motor dimensions were 200-in. diam, 0.73-in. wall, and os-ft length. The inaterial's yield strength was $S_{2}=250000 \mathrm{p} \leqslant 1$. The pressure at failure was 5.2 psi or os"o of provet pressure.

$$
{ }^{J}=\frac{\mathrm{pR}}{t}=\frac{5+2 \mathrm{psi} \times 130 \mathrm{in}}{0.73 \mathrm{in} .}=0,000 \mathrm{psi}
$$

$$
\frac{\sigma}{S_{y}}=0.39
$$



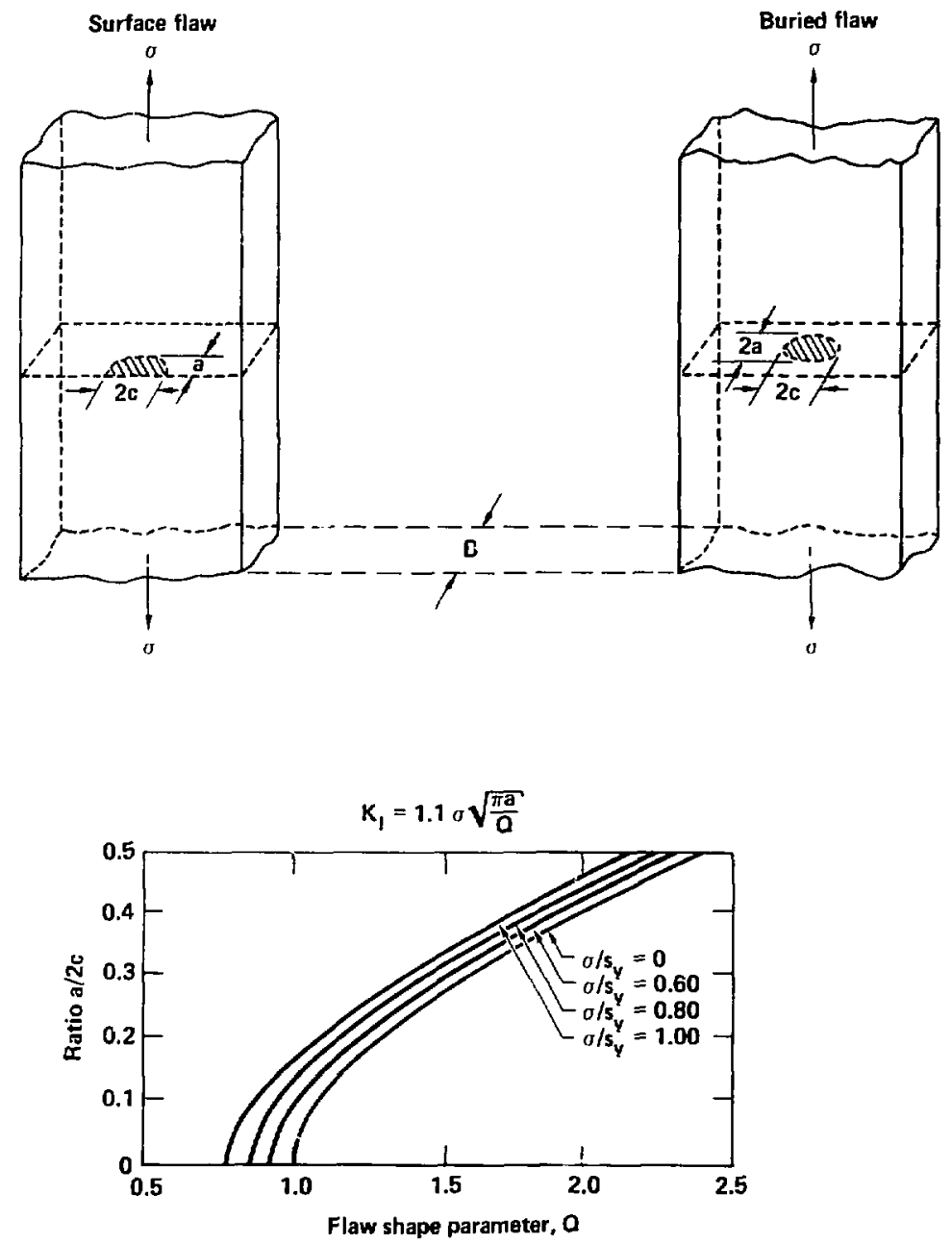

FIC. 3. Buried elliptical and thumbnail cracks and associated stress intensity solutions. 
$\mathrm{a} / 2 \mathrm{c}=\frac{0.05 \mathrm{in} .}{1.4 \mathrm{in.}}=0.036 ; \mathrm{Q}-1.0$

$a=0.05$ in. $=\frac{1}{\pi}\left(\frac{K_{k_{c}}}{\sigma}\right)^{2}=\frac{1}{\pi}\left(\frac{K_{k}}{97000 \mathrm{psi}}\right)^{2}$

$K_{K}=(\pi, 0.05 \text { in. })^{12}(07000$ psi $)$

$K_{1}-38500$ psi-in. ${ }^{12}$

Larger values of $K_{k}$ had been expected for this material. However, subsequent fracture toughne'ss tests showed that the lecation of the crack tip relative to the iveld was an important factor. Alsci the fracture tests exhibited considerable scatter.

Virtually all desgno are the result of numerous cumpromises and trade-offs with respect to cost, wesght, apacity etc. Often because of fracture requirements, the design employing the highest vield strength material will nut result in enther the lightest ar the least expenswe structure. In general. materials with high yield strength have relatively low fracture toughness as in the example above, and smularly: low vield materials have high toughne- flowever, do with all generalities, there are exceptuns. There are some high strength materals that also have high toughness. These materals are usually quite expensive and not readily wanlable. In sume cases their use is limited by either the design envirunment, service temperature, wr both. On the other hanc, some materials have buth low strength and low loughness. Such materials are generally used in lowstress components which are not fracture critical.

\section{BASIS OF A FRACTURE CONTROL PLAN}

A fracture control plan is a specific set of analyses and resommendations developed for a particular stiucture to ensure its fracture integrity. As described by Rulfe and Barsom? ? fracture control plan should contain four basic elements:

1. Mintification of the factors that may contribute to the fracture integrity of a structural member. This would include sorvice conditions and loading (including static, dynamic, and cyclic events), geometric or weld particulars, and required material and fabrication specifications.

2. Einluahun of the relative: importance of each of the factors identified, in particular stress. toughness, and flaw size limitations ( Fig. 4 . Assess the contribution of fatigue crack growth and corrosion leading to the critical flaw size and evaluate the influence of residual stresses and $/: m$ ('mbrittled regons to the design analysis.

3. Ditermmaltu" trith offs and compromises relative tor the varuus design alternatives By considering the influenie of tensle stress. flaw size, and material toughness woth respect to cost design life. load ratung, and range of design appliability, an optinum design can be chosen. Include analysis of the factor af safety and fatinue life considerations. Fur example, for the same quality inspection and fabrication ti.e. same critical flaw size) and mdteral toughness $\left(K_{h}\right)$, a reductuen re! the design stress may be evaluated as an increase in the factor of safety or an extenson of the fiatugue life. These design alternative's should be optumized toward the desired goal.

4. Kanmmonitum, of the spe, if a design considerations to ensure the safety and reliabulity of the structure against failure Such recommendations can include rated capacity or design stress level. material andor fabricatuon qualification. inspection - both initial and as function of life -and allowible environments.

If emploved in an organzed and well thoughtout manner, the fracture control plan concept provides a very useful tool in ensuring the fracture integrity of enginecring structures. 


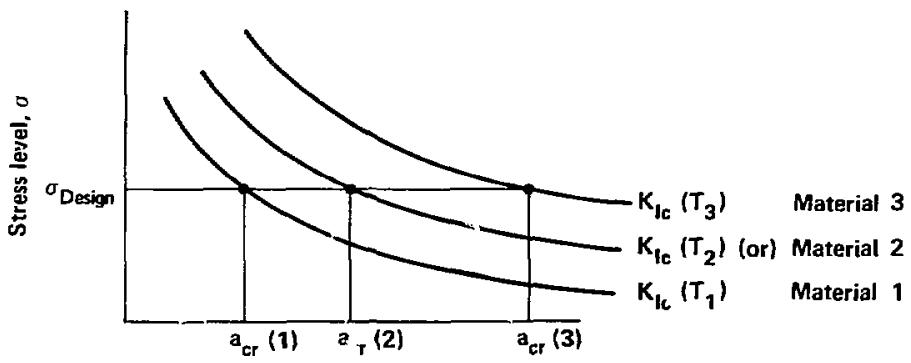

Flaw size, a

Cect of $K_{l c}$ on critical flaw size, $K_{l c}\left(T_{1}\right)<K_{\text {lc }}\left(T_{2}\right)<K_{\text {lc }}\left(T_{3}\right)$

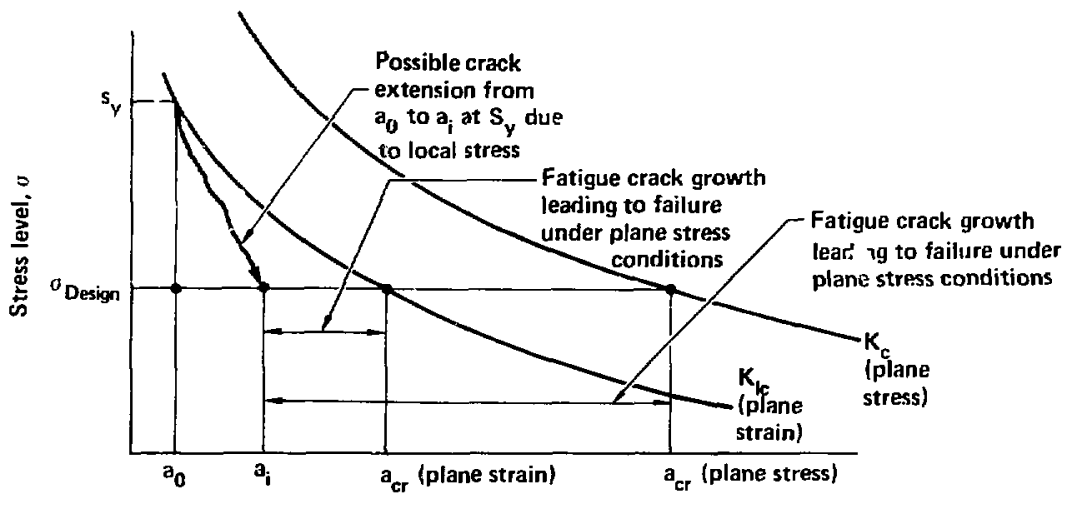

Flaw size, a

Effect of constraint (plane stress vs plane strain) on critical flaw size

FIG. 4. Schematic showing effect of iracture toughness and plane-strain to plane-stress transition (Joss $o^{f}$ constraint) on critical flaw size. ${ }^{2}$ 


\section{FRACTURE CONTROL GUIDANCE}

Relative to the five categories of consequences discussed in the Iritroduction, the fracture control plan can range from a very simple material justification with no testing to one that specifies extensive analysis and testing. In addition to the five categories defined in the Introduction, a sixth category, Category $T$, is defined to cover test or temporary equipment and vessels that fall outside the realm of Categories 1 through $V$. Use of Catego: T design requirements will be very limited.

\section{CATEGORY I}

Because of the minor consequences resulting from failure in Category I components, the fracture guidance is simply based on "good design." No fracture control plan is required. Sharp corners, high stress risers, brittle welds and heat-affected zones, and cracklike geometries should be avoided where possible. Materials used should be compatible with the intended environments and service temperatures, and the stresses should be maintained at a reasonable level relative to the material tensile behavior. Visual inspection of these components should ensure that no gross material and/or fabrication defects exist.

\section{CATEGORY II}

The corisequences of failure in Category II components are more serious than Category I due to the increased cost of repair; however, as in Category I components, there is essentially nol potential for injury or release of hazardous material if the part fails. Thus, although fracture control is still considered a guidance and not a requirement, the moderate cost of failure makes it worthwhile to establish some fracture-safe assurances.

Fracture control for Category II components is based on having the critical flaw size (including environment, fatigue, temperature, and load rate) sufficiently larger than the detectable flaw size as determined by preservice and in-service inspection. In this cise, flaws can be found and repaired before they grow to critical size. Inspection intervals will be set such that a previously undetected flaw cannot grow to critical length pror to the next scheduled inspection. Fracture toughness testing is not required for components in Category II if data are available in the literature. For components fabricated from structural steels, a minimum fracture toughness of $30 \mathrm{ksi}-\mathrm{in} .{ }^{1 / 2}(33 \mathrm{MPa}-\mathrm{m} / 2)$ can generally be assumed as a worst case under most operating conditions exclusive of embrittling environments. As with Category I components, good design judgment is a critical element to ensure fracture safety.

\section{CATEGORY III}

The cost of failure for Category III components are comparable to Category II. However, Category III failures have the potential to cause minor injury. Because of this potential for injury. a fracture control plan is required Similar to Category II components, fracture control will be based on ensuring that a flaw cannot grow to the -itical crack size between inspections even if worst-case operating or accident conditions (e.g., stress, temperature, environment, etc.) are assumed. The maximum allowable flaw size is to be at least as large as the minimum detectable flaw size as determined by preservice and inservice inspection.

The allowable flaw size at a given inspection is determined by calculating what the critical flaw size is (i.e., where $K_{1}=K_{K_{k}}$ ) and estimating how much crack growth is possible between inspection; (considering fatigue, stress corrosion racking, and corrosion-enhanced fatigue). The allowable flaw size is defined as one-fourth the critical flaw size minus the amount of crack extension pussible between inspections. If such a flaw is found, corrective actions are required.

To be considered a detectable flaw, there must be a reliability of $90 \%$ or greater that it will be detected. No flaw less than 0.5 in. $(1.27 \mathrm{~cm})$ will be considered detectable in inspection tinless detection capsbility can be demonstrated in inservice conditions. Flaw sizes significantly greater than 0.5 in. $(1.27 \mathrm{~cm})$ in depth should be assumed if the part geometry is complex or inspection capability is limited.

Fracture toughness tests or dynamic tear (DT) tests will be conducted for the material and 
heat treatment used. Results from DT tests can be used to approximate toughness. ${ }^{13}$ Toughness values obtained from the literature will be acceptable if the material and processing are essentially the same as the specified material. If no data are available and a test is not feasible, a maximum toughness of $25 \mathrm{ksi}-\mathrm{in}{ }^{1 / 2}\left(27.5 \mathrm{MPa}-\mathrm{m}^{1 / 2}\right)$ can be assumed for structural steel. The maximum toughness allowed for an unqualified steel in Category III is less than that allowed in Category II due to the increased risk of injur?.

Other means of fracture-safe assurance may be employed in Category IIl components providing that the integrity of the system can be verified by analysis, inspection, andior maintenance. Redundant members, multiple load paths, and fail-s,afe protection are all viable alternatives.

\section{CATEGORY IV}

Because of the high cost of failure and the potential for injury, brittle failure cannest be tolerated. Components in the Category II' ciassification should be designed such that failure ociurs only after signuficant plastic deformation (i.e., elastic-plastic or fully plastic failure). The critical flaw size for Category il components, hased on tinear elastic tracture analysis, must be ;reater than twice the section thickness under consideration for the worst-case operating or accident stresse's (1,c, a, , 2B), or, through-thickness-yielding must be ensured, i.e., $B=B_{4}$. To ensure through-thickness-yelding in the presence of large sharp cracks in a plate, the thickness B should meet the following requirement:

$B \leq B_{v}=\left(\frac{k_{\mathrm{h}_{\mathrm{l}}}}{\mathrm{s}_{\mathrm{v}}}\right)^{2}$

The fracture toughness and yield strength are based on 'owe'st service temperature and loading rates comparable to the maximum irediale acident. Section thickness up to 1.5 times $B$, can be used if stresses significantly lower than yield can be demonstrated or inspection reguirements eliminate the pentential for brittle tracture.

Material used in Citugory It compenents must be fracture tested using either standard fracture loughness test procedures (ASTM E-390 for $K_{k c}{ }^{14}$ or $A S T M E-B 13$ for $J_{h}{ }^{15}$ ) or dynumia tear test methods. ${ }^{16}$ Relations between dynamic tear lest energies or NDT temperature (nil ductility transition) and fracture tuughness are readily available in the literature. ${ }^{13}$ The single exception to this test requirement is that for iteels, a maximum toughness of $20 \mathrm{ksi}-\mathrm{in}^{1,2}\left(22 \mathrm{MPa}^{\mathrm{P}} \mathrm{m}^{\mathrm{l}}-1\right.$ can be assumed if material testing is not pussible. This value is decreased from that required in Category lil and ItI because of the relative seriousness of an accident should failure ckcur. A frasture control plan is required of all Category II connponents.

\section{CATEGORY $v$}

Because of the potential for infury and ar the release of alazardous or radions tive materiats. no failure can te tulerated. Componessts falling into Category : mist be carefully anolyod and must miect the fully phistic yield a riterion through its iffe-regardless of crach side, enviromment. temocrature, loading or material degradation Section thacknesses jess than $B$, are reyured

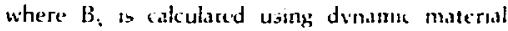
behovior. If the fully plasta ariterate cannet be met, adequate secondary systems must be provided to consure satery and to ade yuately contam

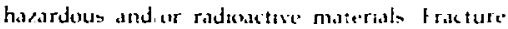
tuughness troting - $K_{i}$ and ar dynamu tear test - is required. A detasled trat ure ontroi phan mast be develeped tor Cotegory I cemponent: Gue-

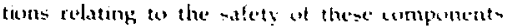
should be reterred to the If butets c immitede

\section{CATEGORY T}

This attegury is established tur compronernts

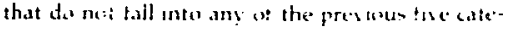
gorres. in particular tius catenory perlans to tent or temporary egupment generally for ane tirne usage." Examples of such anmponcents are remutels loaded test pressure vesecels or struetural members 16 stpport an explesse devere Whate falure of such components may be expensise atten despon or fabricatuon requirements fimat these com-

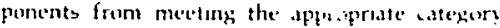
(if safety: In such t.deces, solfets must be ensured

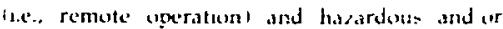
radionctive mitcrials must be contemed Thus. while the component itsolf may not meet the necessary satety reyurements, remote chperatson 
(Ir secondary systems must provide equivalent fracture control.

Low stris alphation. A special case useful for Category $T$ components, where the material properties are not known or the materal is not certified, is to ensure that a fracture-critical component is loadrod to stresse's below a maximum allowable level Basced on the contepts discussed earlier, an alkwable numinal working stress is defined under the following restriction ${ }^{--}$

1. Use the minimum value of fracture toughness available fir the ctoss of materials Low temperature and high loading rate must be arsumed unless otherwse justified.

2. Consuler that a large, underested flaw evist on the structure flus depthe geroster than or equal to half the sectun thichness must be assumed

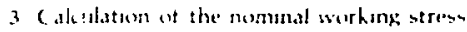
mut malude the effecis of all stress comon. trations as designed intw the structure

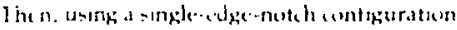

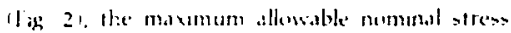
an be ale ulated Jable 1 ,

for : irtually all etructural stede the hereet

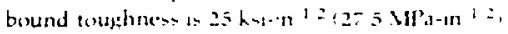

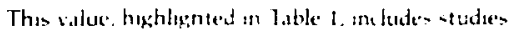

TABLE 1. Maximum nominal stress (ksi) leve] for unqualified materials.

\begin{tabular}{|c|c|c|c|c|c|c|}
\hline \multirow{2}{*}{$\begin{array}{l}\text { Lower bound } \\
\text { fracture touphness } \\
\text { (ksi-in. }{ }^{12} \text { ) }\end{array}$} & \multicolumn{6}{|c|}{ Section thickness (in.) } \\
\hline & $\mathbf{1}$ & 2 & 3 & 4 & 5 & I0 \\
\hline 5 & 1.4 & $\mathbf{I}$ & 0.8 & 0.7 & 0.0 & D.5 \\
\hline 10 & 2.8 & $\mathbf{2}$ & 1.0 & 1.4 & 1.3 & 0.0 \\
\hline 15 & $\$ .2$ & 3 & 2.5 & 2.1 & 1.4 & I. .3 \\
\hline 20 & 3.7 & 4 & 3.3 & 2.8 & 2.5 & 1.6 \\
\hline \pm 5 & 2.1 & 5 & +.1 & 3.5 & 3.2 & 2.2 \\
\hline .90 & $\mathbf{4 . 5}$ & $\mathbf{c}$ & $\$ . \$$ & 4,2 & 3.8 & 2.7 \\
\hline 35 & $\omega$. & $\overline{7}$ & 5.7 & 5 & 4.4 & 3.1 \\
\hline 30 & I I ..3 & 5 & 0.5 & 5.7 & 5.1 & 3.0 \\
\hline
\end{tabular}

(1) welds and he'at-sfferted sone- is alloy and

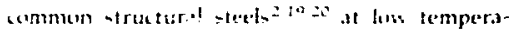

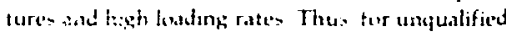
steel strueture the maximum stress that must

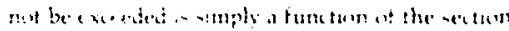

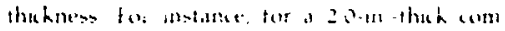
punerse. the masumum nomial tress lecel in

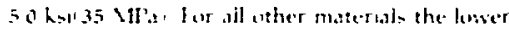

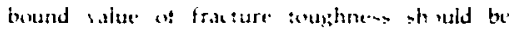

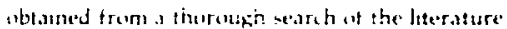

\section{FACTORS IMPORTANT FOR FRACTURE CONTROL}

In the preveres setion- the bask elements of trature methans, and fracture control hase been presented trature antrol gendame were established tor tave tategiories of risk a defined in the Introduction In additum to the gener.l rule: discusedi. the dempner and eneineer must be aware of varues, other factors importint for iracture control These factors are grouped into three sets '11 environment, 12, loxding, and 15 miteraly. Fath of the sets is not independent. however for instance, changes in loadung can effect how an envomment influences fracture Thus. eich of the factors and thes interactoms must be evaluated in fracture-safo design.

Lnewnonst. The serice environment and service temperature can strongly influence beth the safe lite fe.g. stress corrosion crabing and or corrosion fatigue and fracture resistance (e.h. low temperature brittle behavior or hydrogen embrittlement) of a tracture-aritical component.

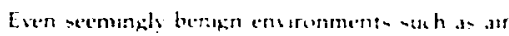
cont.un monture and an hase betrumental efterse

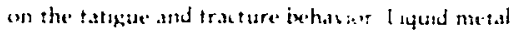
environments alos hace a harge etted an materal

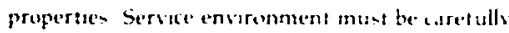

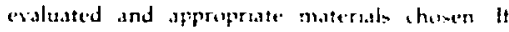
material-emsorenment interactorn in anturpated

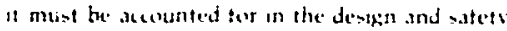
inalyos

Sintmum eprating: tempersture may be the freatess deshn uncertumts smae irature resistance may change markedls in weme samper. ature rangies Dessentong for an unduly low in nerly sofel munmum temperature muy require an encessuely custly mateilal There approprate. operating procedures and comprenent labels should spexify a mininum cperating temperature

Lathms. Loading, whike an important aspect of the dersin analysis, 15 often not well-defined due lu cumplex design peometrses, varmble service 
requirements, and accident conditions. Small cracks may propagate under fatigue loading until the component is weakened and fails by gross overload or until the critical crack size is reached and brittle fracture cricurs. Environment, frequency of loading, and the ratio of maximum to menimum load are factors tiat must be considered in a tatugue andysis.

High rate and impact loading reduces the fracture resistance of most materials If impice loads are anticipated in either normal ar faulted operation, dynamic fracture toughness $K_{l d}$ should be used in the satety evaluation. Intermediate rate loading can aloo have an effect on fracture ressistance, and the corresponding toughness should be used where the loading rate is above static but betow dynantic conditions

ciress concentratuons, such as the rose of threads, increse the stress fevel and thus reduce the critcal tlaw ste. It is important to include all germetru strest risers / stress concentration, weld bead corners. contat points. cete in the stress .11ulyum

A concese set of oprerating limitatione and reciurement for inspection must be specified to ensure that the atual loading and fattgue life do furt exeed the design assessment. If design luading is axceded, the frature critical comporsent sheuld be inspected and repared, andior replaced if necessary

Mifruil Material properties can change dramatually due to temperature, envionment. processing and heat treatment, welding, and radiatu a coposure. Material testing and analysis mist be conducted for the material in the anticipated servire rendition. Welding. for instance. can create lixally embrittled zones, areas of material segregation, and microcracking. As such, it must be assumed that cracks exist in all welded structures When material degradation is expected due to radiation, exiessive heat, or other environmental conditions, a material surveillance program i: acecessary. Such a program requires that spec1mens made from the same material as the fracturecritical componest are stured in the same servite envionment as the fracture-critual component ferenerally adjacent to the fracture-intical compenents. At predetermined tumes throughout the anticipated life of the part, specimens are removed and tested tu ensure that fracture prope rtees haw. nus degraded below acceptable levels

Frixture toughness is often serongly influenced by ursentation of the materal relatise to

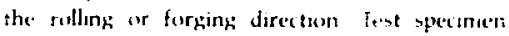

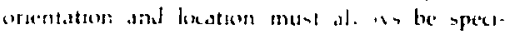

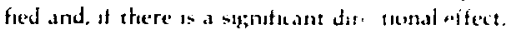
prepier orientation must bo speufued an the design

In all cases in "hohe exuromment. loading: and ar mated bols eftects are a fac lar in the frat ture stety. they must be analyerd and included in the trature contral plan The tngmeermg hemes Dursen wil help an abtamm: intormatum on the inftuence of the important tatter, and wall and in

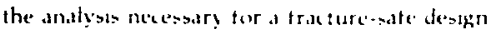

\section{FRACTURE CONTROL SUMMARY}

Table 2, a summary of the fracaure control sudance for the six categories of components. provides a comparison of the different levels of rish. Reter to the sectien an Fratuse (antral

Ciudance for a mone complete analy s: 
TABLE 2. Fracture control guidance summary.

\begin{tabular}{|c|c|c|c|}
\hline Category & Risk & Fracture guidance & $\begin{array}{l}\text { Ftaclure control } \\
\text { plan required? }\end{array}$ \\
\hline I & 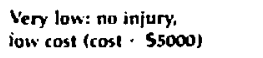 & Good design & No \\
\hline II & $\begin{array}{l}\text { Low: no injury, moderste } \\
\text { cost }(\$ 5000 \cdot \text { cost }=550000)\end{array}$ & $a_{\text {smitical }} a_{\text {inspection }}$ no lesting required. & No \\
\hline III & $\begin{array}{l}\text { Moderate: minor injury; } \\
\text { (first aid). moderate cost } \\
(55000 \cdot \text { cost }-550000)\end{array}$ & 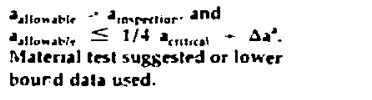 & Yes \\
\hline iv & $\begin{array}{l}\text { High: moderate injury. } \\
\text { ino hospitslization). high } \\
\text { cost (cost S50000) }\end{array}$ & $\begin{array}{l}a_{\text {rritul }} \text { 2B, or } B=\text { B, Material Iest } \\
\text { rcconimended. }\end{array}$ & Yes \\
\hline$v$ & $\begin{array}{l}\text { Very High: severe injury } \\
\text { andior release of hazdrdous } \\
\text { materi } 3 \text { l }\end{array}$ & $\begin{array}{l}\text { Design for iully plastic behavior required. } \\
\text { B. B. Material test required. }\end{array}$ & Yes \\
\hline $\mathbf{T}$ & $\begin{array}{l}\text { Varies: test or temporary } \\
\text { equipment }\end{array}$ & $\begin{array}{l}\text { Design option: No injury or relesste of } \\
\text { harardous material accepted. }\end{array}$ & Optional \\
\hline
\end{tabular}

't is the crack prowth anticipated beiween inspections.

\section{ACKNOWLEDGMENTS}

I wiould like to thank Jrofeson I Finn of the Unversity af California, Berkeley for his advice. examples. and for his revew if the manuscript. The work was completed under the gutudance of the Mechanical Enginterms' Fracture ( ont rol Committee and the Mechanical Engineering Department Safety Committee. 


\section{REFERENCES}

1. H. Mchenry and S. T. Rolfe, Frature Control Praclices for Mefal Structurs, NBSIR 79-1023, National Bureau of Standards, Jan. 1980.

2. S. T. Rolfe and ). M. Barsom, Fraciurc and Faligue Cuntrol in Struturts (Prentice-Hall, Inc., New lersey, 1977).

3. Frasture Mtchanics in Engiustring Proctici. P. Stanley, Ed (Applied Science Publishers, Londan, 1977).

4. Health and Safity Mantul. Lawrence Livermore National Laboratory, Livermore, CA, Manual M-010 (current issue).

5. Disign Sifte! Stamiards/Merlumical Engintering Dipartment. Lawrence Livermore National Laboratory, Livermore, CA, in preparation (1982).

o. W. S. Pellini, Mantal of Enginering Profidures for Frathre-Safe Design. Association of American Railroads, Chicago, IL, AAR Report Ii451, Nov. 1980.

7. American Society of Mechanical Engineers (ASME), Boiler and Prosilre Vrsid Colt. Section III-NB-2.300, NC-2300. Appendix C (1981).

8. E. M. Ehret, "Material Control and Fracture Cuntrol Planning for the Space Shuttle Orbiter Program," in Structurul Integrity Torhology. ASME (1979).

9. I. M. Barsom, "Development of the AASHTO Fracture-Toughnesa Requirements for Bridge Steels," Engum. Frikl. Worh. V7 (1975), pp. 605-618.

10. C. M. Hudson and S. K. Seward, "A Compendium of Sources of Fracture TC-ghness and FatigueCrack (irowth Data for Metallic Alloys," Int. I. of Fracturt, 14 (4) (1978), pp. R!51-R184.

11. H. Tada, I'. l'aris, and C. Irwin, The Stres Andisis af Craks Hamlbok. Del Research Corp., Hellerto vn, P:(1973).

12. D. I'. Rooke and D. J. Cartwright, Commenditum of Stress lntensity Factors (H. M. Stationary Office, London, 10701.

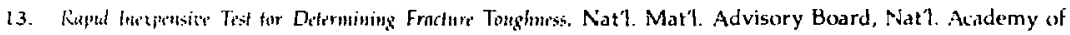
Sciences, NMAB-328 (1970).

14. American Society for Testing and Materials (ASTM), Annual Standards, E390-81. Part 10 (1981).

15. American Society for Testing and Materials (ASTM), Annual Standards, E813-81, Part 10 (1091).

10. American Society for Testing and Materials (ASTM). Annual Standards, Eo07-80. Part 10 (1081).

17. R. Streit, Memorandum MTE80-1 to A. Blake, Lawrence Livermore National Laboratory, Livermore. CA, Jan. 8, 1980 .

18. E. Banks, "Toughness Properties of HAZ Structures in Structural Steel," IVIdimg Kris, Sujp. Welding I. 53 (!97+). pp. $299-306$.

19. R. O. Richie, I. F. Knott, and I. R. Rice, "On the Relationships between Critical Tensile Stress and Fracture Toughness in Mild Steel," 1. Mich. Phys. Solhts, 21 (1973), pp. 395-410.

20 A. K. Shoemaker and S. T. Rolfe, "The Static and Dynamic Low-Ir.nperature Crack-Toughness P'erformance of Seven Structural Steels, Engine'ring Fratur' Meihamis. 2 , June 107I, 